\title{
Knowledge-oriented business process management as a catalyst to the existence of network organizations
}

\section{Olga Sobolewska ${ }^{1}$}

\begin{abstract}
Nowadays, more and more often, we are dealing with the emergence of network organizations. These are organizations set up to accomplish specific tasks and are created by unrelated organizations. Choosing such a partner cannot be and is not accidental. It is a process in which knowledge about a possible partner and its resources as well as opportunities are used. The author puts forward the thesis that the organization's orientation both on business processes and knowledge management is a strong determinant for undertaking network cooperation. In order to verify such a formulated question, a questionnaire was carried out. Questions about factors influencing the decision about undertaking cooperation in the network structure were directed to a non-random group. The organizations that participated in the study have experience in running projects within the network structure. The study is of a contributing nature, but it can be a starting point for further considerations and for an attempt to build a model of a general nature.

Keywords: network organization, business process management, knowledgeoriented business process management, cooperation determinants, process of knowledge management, flexible organization
\end{abstract}

\section{INTRODUCTION}

The modern market requires organizations to be flexible. This flexibility is understood as the ability to quickly adapt to new market requirements in various areas of operation, such as the company's systems (including IT), structure, and even organizational culture. These challenges are usually encountered by network organizations, whose operation is often conditioned by the existence of a specific project or order. The article aims to show the

1 Olga Sobolewska, Dr. Eng., Warsaw University of Technology, Management Department, Narbutta 85, Warsaw, Poland, e-mail: olga.sobolewska@pw.edu.pl (ORCID ID: http://orcid.org/0000-0002-5377-2480). 
interdependencies between organizations with a network structure and process-managed organizations that are associated with the traditional orientation and relatively low flexibility. A question arises as to whether it is possible to combine these two, seemingly contradictory, entities. A hypothesis is put forward that this is not only possible but also common in management practice. Furthermore, it is argued that network organizations constitute the future of management, given that process efficiency, and in particular, the efficiency of knowledge-oriented processes makes the organization attractive and is a strong asset when it comes to seeking project partners.

The research hypothesis put forward in the article says that the business process management efficiency of the organization being a member of a network organization has a positive impact on the effectiveness of the whole project. To define this relationship, questionnaire surveys were carried out with the participation of business, scientific, and public-benefit organizations. The article presents the concept of business process management and its evolution. A contemporary tendency in business process management has been shown, which from the classic engineering, optimization approach, turns towards knowledge management as one of the key resources of the modern organization. Organizations with a network structure were also presented as an example of structures built for the full use of partners' knowledge and resources. It also indicates the factors determining the establishment of a cooperative relationship between unassociated entities. One of the most important arguments justifying such cooperation is the process excellence of the partners. It is a way to use inaccessible resources and the opportunity to develop knowledge resources, so important for modern organizations.

\section{LITERATURE BACKGROUND}

\section{Knowledge-oriented business process management as a concept - evolution of meaning}

Business process management understood as the orientation and improvement of processes implemented within the organization is an approach that goes hand in hand with management sciences. Traditional management in an organization used to rely on the assumption that it is necessary to develop operating systems that are as transparent as possible to their contractors. Due to the fact that organizations used to employ or work with low-qualified employees, the relationships between organization members were very simple, whereas learning roles merely required longterm repetition of the same activities. The division of responsibilities was 
strictly defined, too, with the educated and decision-making superior at one end, and the order-executing employee at the other (Grajewski, 2012).

The precursor of business process orientation is Porter (1985), who, along with the concept of the value chain, pointed to the need to integrate it and its interoperability. This concept was continued by Deming, who showed in a flow diagram the links between organizations from the customer to the supplier as a process that can be measured and improved, as is the case in production processes where an even better solution is sought (Deming, 1986; McCormack \& Johnson, 2001). Business process orientation allows organizations to think together as one unit to increase efficiency in meeting customer needs (Nadarajah \& Kadir, 2016).

The process is a sequence of events related to each other in a cause-andeffect manner, which are stages, phases, stages of development (Hofman \& Skrzypek, 2010). The goal of the process is, as Hammer and Champy write (1996), to provide the customer with a specific service or product. A similar approach focused on satisfying market needs (dictated by the organization's environment), can be found by Rummler and Brache (2000). More and more often, along with the development of management sciences, it is evident to indicate an equally important source for process improvement, which is strengthening and improving the customer relationship not only with external customers but also internal ones (Hofman \& Skrzypek, 2010; Szczepańska \& Bugdol, 2016; Nadarajah \& Kadir, 2016).

The constantly changing requirements and expectations of the market towards the organization, the declining life cycles of the products or the permissive volatility of both international clients and the world-wide crowded competition, force companies to look again at the processes of the company. As a result, business process management (BPM) is one of the most important tasks for management. It is not limited to production processes, but its range begins to cover the whole spectrum of organization management, becoming a holistic management philosophy (Choong, 2013, Ravesteyn \& Batenburg, 2010).

The performance and effectiveness of the operation of a business processmanaged organization is a direct derivation of the efficiency of the processes carried out in them (Bitkowska, 2018; Gabryelczyk \& Roztocki, 2018). A condition conducive to such improvement and enhancement of the organization's functions is the existence of static processes, i.e. those that provide a detailed description of said functions in the form of an algorithm of action. Today, however, increasingly fewer processes taking place in organizations are static. Research indicates that, depending on the industry, only $20-40 \%$ of all processes are static, with this value having shown a downward trend over time (Szelągowski, 2018, p. 48). Static processes are undoubtedly those regulated by 
law, patents, licenses and concessions, and as such, they are strictly subject to objective restrictions (laws of physics or chemical reactions).

The ongoing changeability of the environment, increasing customer expectations, and competitive pressure, require the organization's readiness for flexible operation. At the highest level, flexibility should be understood, above all, as the ability of the organization to adapt its own functioning to changes occurring in the environment, which have not been previously foreseen. This means that the organization should be able to learn, adapt to the environment, and quickly redefine internal tasks, systems, and structures. It is becoming increasingly more common for processes taking place in the organization to be volatile. Organizations participating in the market constantly exchange with the environment, and as a result, they have to agree to adapt to its constantly changing external conditions (Gabryelczyk \& Roztocki, 2018). This also affects the processes occurring within these organizations, which also need to be subject to more or less profound changes, which applies in particular to those activities that are associated with the creation and provision of value, products or services to the customer. Increasingly often, organizations need to personalize their product or service to meet market needs, which by default prompts them to introduce certain changes to their previous activities. In this way, processes taking place in organizations are becoming less and less static (Figure 1).

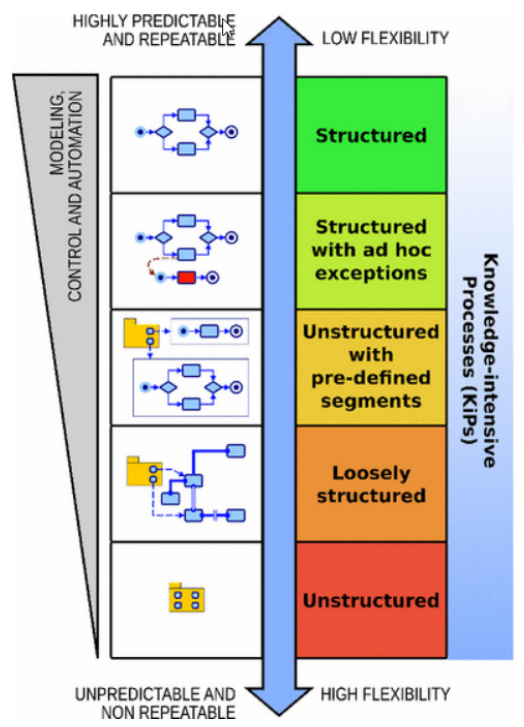

Figure 1. The spectrum of process management Source: Di Ciccio, Marella \& Russo (2015, p. 6). 
Under such conditions, a natural consequence is the modification of the view of business process management, which evolved from the traditional approach typical of industrial engineering and assumptions about the invariability of the process. In classical terms, process modifications consisted of eliminating redundant activities and a gradual but slow improvement in line with the Deming Cycle. Today, this model is being replaced by the adaptation of processes that take place in organizations to customer requirements, as well by approaching business processes and knowledge as two inherently linked elements (Bitkowska, 2018; Szelągowski, 2018) (Figure 2).

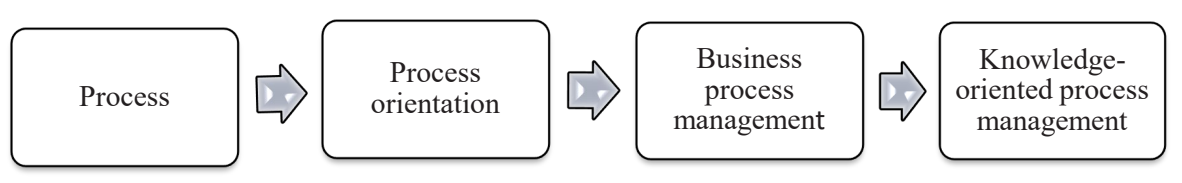

Figure 2. The evolution of business process management Source: Bitkowska (2018, p. 21).

Knowledge-oriented process management should integrate two parallel approaches - managing the processes taking place in the organization in order to improve and optimize those processes, as well as the approach resulting from the management of non-material resources of the organization. The processes taking place in the organization should not only focus on the excellence in the production of services or products, but also on the fact that the natural product that arises as a result of the process is knowledge. The fact of creating an intangible asset as a result of business process management should be taken into account at each level of the production process implementation, and the knowledge management processes themselves become "a fundamental task and the challenges of our time" (Claver-Cortés, Zaragoza-Sáez, \& Pertusa-Ortega, 2007).

Knowledge is a resource that should be dynamically managed by any organization that hopes to achieve a competitive advantage (Birkinshaw \& Sheehan, 2002; Chen, Huang, \& Hsiao, 2010; Hamel, 2007; Mills \& Smith, 2011; Kisielnicki \& Sobolewska, 2018). Knowledge management is a conscious strategy of acquiring the right knowledge for the right people and delivering it to them at the right time. But it is not everything. The full process of knowledge management also takes into account the sharing of knowledge, as well as the "release of knowledge" so that the use of knowledge will improve the efficiency of business processes and ultimately improve the organization (O'Dell \& Grayson, 1998). Constant changeability, which is an opportunity and, at the same time, the fear of modern organizations, means 
that knowledge management and the integration of these processes with manufacturing practices contribute to increasing innovation. "Organizations are interested in their customers and increasing their productivity" (Nguyen \& Mohamed, 2011, p. 206).

The process of knowledge management introduced by Davenport and Prusak (1998) included three basic activities: knowledge acquisition, codification, and distribution. As part of the process of acquiring knowledge, the organization should actively seek sources of information and knowledge, classify the information obtained (selection and its evaluation), acquire new knowledge and take care of its continuous creation as a result of the processes taking place in the organization. Codification and transfer of knowledge consist of preparing knowledge for a form in which it can be used. It can be done by entering data into databases or preparing appropriate data repositories that are useful, convenient and available almost "on-demand" for members of the organization. The significance of the fact of using knowledge for the needs of the organization's activity was shown in the process, which is shown in Figure 3.

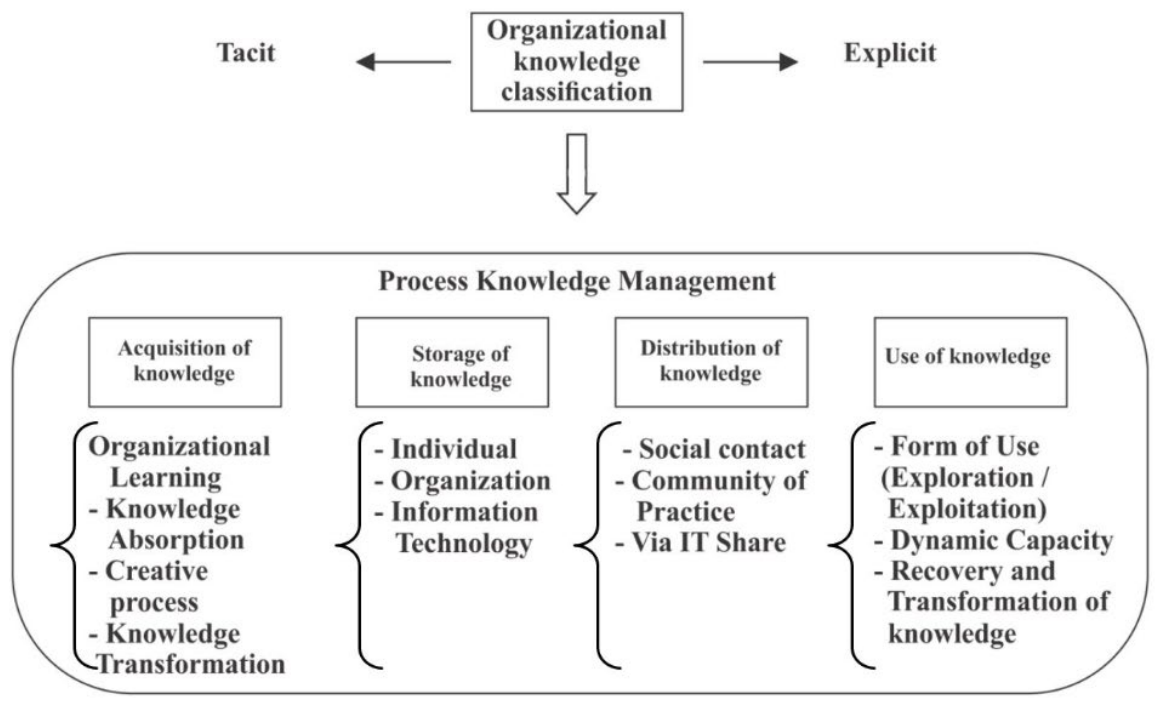

Figure 3. The Knowledge Management Process

Source: Kakabadse and Kakabadse \& Kouzmin (2003). 
The knowledge must be used as a basis for the development of new knowledge through integration, innovation, creation, and extension of the existing knowledge base, and should continue to be used as a basis for decision-making. Knowledge management enables organizations to make decisions and, at the same time, knowledge is an element that forms the basis for creating new knowledge through innovation (Nooteboom, van Haverbecke, Duysters, Gilsing, \& van der Oord, 2007; Ganzaroli, de Noni, Orsi, \& Belussi, 2016). The new knowledge is build based on already existing knowledge. An interesting, and at the same time, a very important approach can be seen in Walsh and Ungson (1991), who wrote about the use of knowledge on two levels: automatic and controlled. Automatic use of knowledge is a routine activity that is developed in an organization through procedures, structure, or organizational culture. However, as the complexity of activities increases, or as changes take place, non-routine activity is required, and it is necessary to look for unconventional knowledge, often located in different repositories, or the need to create it. This requires an organization of flexibility, which Teece, Pisano, and Shuen (1997) defines as "[...] the ability of the firm to integrate, build, and reconfigure their internal powers in order to quickly respond to the environmental changes."

Examples of such dynamic capabilities of an organization may be research and development activities, alliances and acquisitions, technology transfers, and procedures (Zollo \& Winter, 2002). Such activities are part of the knowledge management process in the organization and are directly derived from the learning process while being a gradual and systematic (if they are regularly undertaken) method of modifying the organization's routine and its routine, automatic knowledge management process. These mechanisms constitute a cycle of knowledge evolution. This cycle implements research and exploitation in order to seek solutions to the hidden needs of the environment and transform these solutions into procedures.

The form of acquiring and developing knowledge resources does not have to be taking over another organization or technology transfer, but it can also be undertaking cooperation activities. Nowadays, more and more often, this cooperation takes the form of an organization with a network structure, which is a derivative of the development of an IT network. Modern organizations, as part of their goals, are not limited to their resources, but increasingly use the possibility of establishing cooperation with other entities, unrelated to the capital of the organization. 


\section{Network organizations}

The digital revolution, of which we are both witnesses and active contributors, covered the sphere of management to a large extent (Brynjolfsson \& McAfee, 2015). This impact is visible both in the take-over of broader areas of organizations' management through IT systems (e.g., the already extremely common automation of production and the increasingly progressive automation of other areas of the organization), as well as changes in the organizations themselves and their organizational structures. Contemporary organizations are less and less reminiscent of those from a decade ago. Classical organizations, organized in a hierarchical manner, undergo a peculiar path of evolution. In the 60s of the last century, one could observe the transformation of classical linear organizational connections into matrix structures, aimed at improving management and facilitating project management. Today, we are increasingly observing the flexibility of these structures towards network and self-management organizations (Robertson, 2015). The creation of this type of organization, to a large extent, is conditioned by the development of networks and information technologies (ICT). Networking of the organization does not only mean the way of formal organization of the structure but, to a much greater extent, indicates their way of functioning. Network organizations are currently created to strengthen and better use knowledge resources, which directly affects the improvement of the efficiency of business process management in the organization.

All organizational activity intended to achieve predefined goals requires the commitment of resources. As the scope of activities undertaken is broadening and the complexity of tasks carried out is growing, these resources have to be more and more differentiated, and increasingly numerous. Initiating new measures requires the organization to make decisions concerning its relations with an environment. The ability to create competitive advantages is the factor which to a great extent determines future actions of the organization and influences its attractiveness for other market players. The aforementioned competitive advantages are built on the basis of resources owned or used by the enterprise. Traditionally, enterprise resources are divided into two categories: tangible and intangible. Tangible resources include fixed assets, real estates, machines, raw materials, and financial resources. Intangible resources consist of various procedures, operational models, know-how, owned patents, and the human factor employees and their experience, knowledge, skills. The classical definition of a resource states that it must be valuable, rare as well as difficult to copy and substitute. Dollinger (2002) enumerates 6 types of strategic resources 
of the undertaking (PROFIT formula): physical, reputational, organizational, financial, intellectual, human, and technological.

One may notice more and more discussions about global competitive advantages, which are the result of efficient links between national circumstances and the company's strategy (Porter, 1985). Even the operational excellence of an enterprise resulting in achieving leadership cannot guarantee success in a new market. Available resources constitute one of the pillars of the strategy, the second one being the surrounding of the organization. In the case of business organizations, we usually talk about a competitive (market) environment where a customer is able to choose a supplier. In such a situation, the position can be expanded to new markets and new segments, and the actual market power can be strengthened through the strategy of finding a business partner. The current competitor can turn into a kind of partner (coopetition).

Coopetition is the relation of cooperation where at least two entities share selected resources with the aim of achieving common objectives. Characteristic features of coopetitive relations, which are emphasized in numerous publications and which are reflected in definitions of this notion, are as follows (Pronshikh \& Sobolewska, 2018):

- the duality of relations - the co-existence of competition and cooperation, which is possible due to the division of areas devoted to specific actions as well as to the effective coordination of activities performed by cooperating organizations in these distributed operational zones;

- interdependence - which is demonstrated by the mutual dependence of parties involved and also by sharing resources submitted to the coopetitive relation in any form (as an item, a qualification or a skill);

- long-term character of the relation - the longer perspectives of cooperation, the more eager the partners are to start collaboration; the duration of cooperation also affects the amount and the variety of contracts signed within the framework of coopetition as well as the internal structure of this interaction;

- openness - the cooperation must exist between two or more organizations; yet, there is no limit on the number of parties involved; the openness also concerns markets which take part in this coopetition, because collaborating parties do not have to be exclusively direct competitors; cooperation can take any form or scope - the will of the parties and the capability of jointly identified goals are the only decisive factors in this case. 
Network organizations are the result of the transformation of traditional structures, organized in a hierarchical manner, into modern forms functioning due to the use of information technologies. These are structures that they do not relate to, as much as in the case of classical organizations, functional and geographical limitations. The motive power for them is the ICT network, thanks to which they can, without major obstacles, exceed geographical and institutional boundaries. M. Castells even talks about a new type of economy (information economy), which replaces the old type of industrial approach (Castells, 2007). While in the previous type of economy a competitive advantage was generated due to economies of scale, now the new economy is guided by the economics of the network, which consists of increasing the coverage of the network, and the network can significantly increase its value by connecting to other networks. The creation and functioning of network organizations in the conditions of a new approach to management is caused by the desire to search for modern and non-standard solutions, knowledge development, and supporting innovation.

Network organizations are organizations that arise as a result of a combination of different, often independent, units. This connection can be of a temporary nature, often limited to the implementation of a defined, specific task. Collaborative relations between organizations may be of a different nature, they may concern both material and intangible resources of the organization (Zott \& Amit, 2010). The basic goal that guides the creation of such structures is to achieve a synergy effect, faster or more effective implementation, thanks to the combination of resources and objectives. Hence, in network structures, particular attention can be paid to information connections.

Stańczyk-Hugiet, as the basic motive for the creation and functioning of network structures, indicates "the benefit obtained from running a business," which he describes as an economic pension (Niemczyk, StańczkHugiet, \& Jasiński, 2012). As a factor determining the existence of network organizations, Mikuła (2006) indicates a reduction in transaction and transport costs, which are often accentuated as the next effect of the digital revolution. He also emphasizes the fact that the creation of a new type of organization, so separate from the existing organizational forms, requires its members to develop new styles and management models. This need, resulting from the need to strengthen cooperation between self-governed teams of experts and to facilitate their fast and effective communication in order to achieve the objectives adopted by the network organization, is also emphasized in the works of Kirkpatrick (2011) and Hamel (2007). It is also a way of limiting the risk and uncertainty associated with running a business, especially in emergency situations, because the network makes it possible 
to transfer some of the threats to its participants. Niemczyk even writes about a specific "bypass system" (Niemczyk et al., 2013) in the context of risk management for network organizations that "gives a sense of greater security in a market competition situation, means greater resource flexibility, fewer capital needs" (Łobejko, 2012).

Brilman (2002) lists four types of network organizations: integrated networks, federated networks, contractual networks, direct relations networks. In the business context, three main types of network organization are mentioned (Snow, Miles, \& Coleman, 1992):

- inner, where, in the framework within a large organization, there are separate units acting as profit centers;

- stable, where the company (the parent company) is in the center of the organization ordering work for other related organizations. These are long-term connections;

- dynamic, these are temporary alliances, taking the form of agreements with other organizations that provide key (both tangible and intangible) resources for the agreement.

Organizations undertaking cooperation within a network organization choose various forms of connections: strategic alliances, clusters, or co-op relations. The main goal of each of these organizational forms is to achieve goals that would be unachievable for an alone organization. However, this is not a typical activity only for business organizations. It is more and more often, a form of reception by territorial administration units (Bartkowiak \& Koszel, 2015; Matthews \& Schulman, 2005) or health services (Baretta, 2008). It is also an extremely popular form of operation in the functioning of scientific organizational units (laboratories, research institutes, universities). Among the benefits that result from joint action, the most frequently mentioned are: gaining access to valuable, from the point of view of the organization's goals, resources, increase in innovation, reduction of operating costs, as well as expenditure on research and development. All these factors translate into strengthening the competitive position of the organization, and may also be one of the methods of eliminating operational risk.

Cooperative action in the form of a network offers organizations the opportunity to use not only their own knowledge, skills, and competences but also those of their partners. For an organization, it is a chance to build or strengthen its market position. An important role in network arrangements is played by ICT systems that support the development of new models of work, communication, and collaboration. In consequence, more and more various organizational networks are being established as "extended organizations." 
(Tubielewicz, 2013). These are structures that are strongly focused on sharing, exchanging and generating knowledge, skills, and competences, thereby often being the place for innovative solutions. A network is a model or metaphor that describes a system of relationships among a specified number of units. While this number can be very large in social relationships (the case of social networks), it is usually clearly defined in economic relationships. These relationships include (Kisielnicki \& Sobolewska, 2018):

- links and interactions among units within the network, where links are long-term and interactions are short-term relationships;

- structure and position understood as the interdependence of the elements that make up the network and, as a result, the way in which they form interrelationships;

- process understood as a change of ties among companies as an effect of jointly implemented tasks.

For enterprises, it is becoming necessary to cooperate in the development of new products or in a wide range of activities called innovation development. This is determined by the high cost of research and development activities that can represent an impassable barrier for an individual company (Merrifield, 2007). Such constraints are encountered not only by small and medium-sized enterprises, which have limited resources because of their structure. It turns out that also "giants" are more and more frequently seizing the opportunity for cooperation. Particularly spectacular cooperation is present in automotive markets where manufacturers have been working together for years to build modern cars and engines, or where, as announced by Toyota, Nissan, and Honda in early 2015, they are declaring cooperation on the development of hydrogen stations for modern FCVs (Fuel Cell Vehicles). It should be noted that it is neither the first nor the last such cooperative relationship established in the automotive market.

Similar collaborative relationships are perceptible in virtually all sectors of today's economy. The need to develop cooperative relationships ensues from two groups of factors: internal, resulting from the specificity of the organization itself, the way of management, goals, and strategies, and the organizational culture in place (Cygler, 2009). The second group of factors influencing the willingness to collaborate includes sectoral factors (Table 1) that differ considerably in the case of business and scientific entities. Regardless of the sector and the specificity of the organization itself, the development path (and the pace of market changes), however, requires organizations to be prepared for a variety of actions including cooperation. 
Depending on its scope, such cooperation will vary in nature. It can be pursued within a single organization when collaborative relationships are established by independent branches and departments. It may be very broad when representatives of organizations outside the sector where the initiator is active are invited to cooperate.

Table 1. Impact of sectoral factors on the cooperation of enterprises and universities

\begin{tabular}{|c|c|c|c|c|c|c|}
\hline \multirow[t]{2}{*}{ Sector parameter } & \multicolumn{3}{|c|}{$\begin{array}{l}\text { Impact on business } \\
\text { cooperation }\end{array}$} & \multicolumn{3}{|c|}{$\begin{array}{l}\text { Impact on university } \\
\text { cooperation }\end{array}$} \\
\hline & low & middle & high & low & middle & high \\
\hline Technological advancement & & & + & & & + \\
\hline Susceptibility to globalization & & & + & & not applicał & \\
\hline Intensification of competition & & & + & & + & \\
\hline $\begin{array}{l}\text { Concentration of the sector's } \\
\text { structure and intensity }\end{array}$ & & + & & & & + \\
\hline $\begin{array}{l}\text { Profitability and growth rate of the } \\
\text { sector }\end{array}$ & & + & & & + & \\
\hline Entry barriers & & + & & + & & \\
\hline Confidence in supply & & + & & + & & \\
\hline The threat of substitutes & + & & & & + & \\
\hline Sector's age & + & & & & not applicak & \\
\hline
\end{tabular}

Such a relationship occurs in the case of clusters, where the cluster consists of representatives of business, science, and administration, and sometimes even representatives of the third sector, which is non-profit organization.

Nonetheless, regardless of the scope of collaboration and the number of partners in the relationship, the optimal form of its implementation is the network structure. It is a consequence of going beyond a rigid organizational structure and related connections. Successful transfer of knowledge and technology between participants in a network organization requires mutual relationships to be built up. Such relationships will occur in the following areas: scientific partnership, research services, academic entrepreneurship, human capital mobility, commercialization of intellectual property rights, and scientific and popular science publications. Knowledge and technology are most often transferred between these entities through the appointment of a researcher/researchers acting for the university and representatives of the company. Such cooperation is governed by contracts, draws on the experience gained during the implementation of other projects, and is easier thanks to the previously developed network of contacts. 
The need to cooperate, within network structures, that is, those that extend beyond the boundaries of the organization has become the everyday life of modern companies. In the introduction of the article, the assumption underlying the study is marked. It is an assumption that modern organizations are increasingly undertaking cooperation activities. They do it for the implementation of various types of projects. One of the important factors that determine the selection of a partner for the implementation of the project is the opinion on its efficiency in business process management, including knowledge processes. Network organizations are structures that carry out complex projects, often going beyond the boundaries of one industry. Therefore, they are aware of the need to dynamically acquire knowledge by creating alliances and networks of cooperation. The hypothesis put forward in the article says that high-quality business process management influences the effectiveness of the network organizations.

\section{RESEARCH METHODS}

The research hypothesis adopted in the study says that the process efficiency of an organization being a member of a network organization has a positive and significant impact on the effectiveness of project implementation.

For its verification, the main hypothesis was decomposed into two partial hypotheses:

H1: Organization with high-quality management of its internal processes is an attractive partner in the process of creating a network organization; $\mathrm{H} 2$ : These processes are becoming a key resource in the implementation of network organization tasks.

On the basis of the literature review and factors that influence the decision to start cooperation, a research questionnaire was prepared, which consisted of 9 questions. In each of the questions asked, the respondents were asked to indicate the answer using a five-point Likert scale, from 1 (least meaning) to 5 (the most important factor). The questionnaire was sent by e-mail in April 2019 to each organization with a request for a reply. The survey was addressed to people holding managerial functions in organizations and carrying out their tasks in a networked manner. These were people who participated in the decision-making process to undertake cooperation activities in a network manner or had access to information about the conditions and criteria for such cooperation. Therefore, the research sample (Table 2) was limited to persons who perform managerial functions or are responsible for managing the part of the organization's activities (project managers or task managers). 
Table 2. Organizations participating in the survey - breakdown

\begin{tabular}{lll}
\hline Sample characteristics (affiliation) & N & \% \\
\hline University & 26 & 29.89 \\
Scientific laboratory & 13 & 14.94 \\
Public & 9 & 10.34 \\
Business & 39 & 44.83 \\
Total & 87 & 100 \\
\hline
\end{tabular}

The survey, after rejecting answers given as incomplete (8 questionnaires), was completed by 87 people. The questionnaire interview was not random, because the survey invited individuals who, over the last 5 years, undertook networking activities. Organizations representing both business and the public sector and science participated in the study.

\section{STUDY RESULTS}

The study formulated two partial hypotheses. The first one concerns the factors influencing the decision to start cooperation in the network structure. In particular, it focuses on the importance of quality in process management as determinants for undertaking such a form of cooperation. The organizations that participated in the survey indicated in the vast majority that they have a constant network of partners developed as a result of subsequent projects. This is especially visible in the case of scientific institutions, which, as is evident from the statements of the respondents, strive to build a network of connections. It is visible in Figure 4, which shows the answer to the question about whether the organizations have permanent networks of partners with which they continue cooperation after previous, positive project experiences.

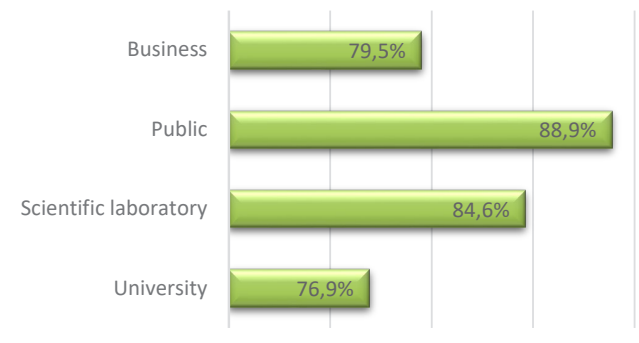

Figure 4. Weighted averages for answers to the question about the existence of a network of collaborators for respondents representing various market sectors 
The question posed in the survey concerned the motives (reasons) for cooperation in network structures (Cygler, 2009; Sobolewska, 2016). These are internal factors resulting from the specificity of the company, the model of management, objectives and strategy, as well as the relevant organizational culture. The factors included:

- complementarity of resources understood as the opportunity to supplement own, often insufficient, resources (both tangible and intangible) by means of access to those available to a partner in a network organization. That is the factor most often emphasized as being decisive in the responses given by scientific entities, but it is also increasingly often ${ }^{1}$ viewed as significant for the operation of business units. Access to resources through networking is often a strategy to meet market needs in the fastest possible way. This is often a necessary condition for the emergence of innovation and its subsequent effective implementation;

- opinion regarding quality of resources. Organizations deciding to cooperate do this in a non-random way. This factor is closely related to the previous one, as the partner's resources for cooperation are expected to be not only complementary, in relation to those available to the organization, but they also have to meet the quality criterion. It should be noted that this requirement does not always related to the highest quality, as organizations are not always able to estimate it, or they simply do not have enough bargaining power. Quality, in this case, means meeting the organization's requirements. The definition contained in the ISO 9001 standard can also be recalled, where quality is understood as "(...) the degree to which a set of inherent features meets requirements" (ISO, 9001: 2000). In this case, the concept fully reflects the viewpoint of the survey participants;

- reputation enjoyed by the organization;

- ability to interact/experience, which stems from earlier cooperation activities undertaken by the organization. This is strongly related to the reputation of the organization as a partner for cooperation;

- system of connections with other organizations understood as a network of available collaborators, a network of internal contacts that have an impact on the organization's knowledge resources;

- convergence of organizational cultures;

- adjustment of organizational structures of the organizations cooperating with each other;

- organization size symmetry;

- convergence of goals and strategies.

1 Reference to previous research which analyzed factors influencing decisions of cooperation for business organizations and scientific entities (Sobolewska, 2016). 
Answers pointing to the significance of individual factors in the decision to undertake network cooperation are illustrated in the graph in Figure 5. Participants of the study provided answers using a 5-point Likert scale, where 1 meant a completely insignificant factor and 5 a factor of the highest importance. In Figure 5, the results are shown using the weighted average of all 87 responses.

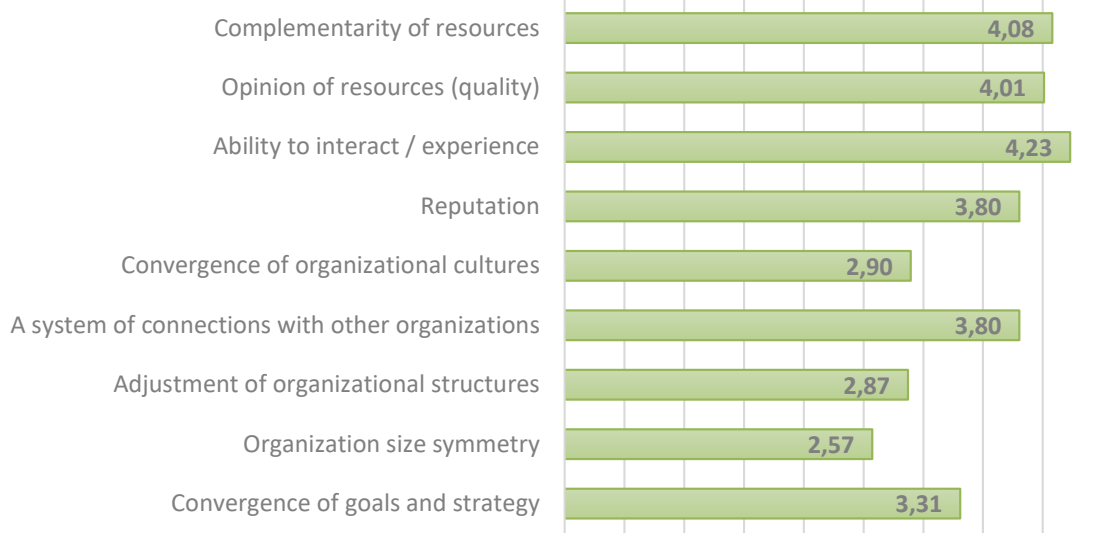

Figure 5. Weighted averages for the answer to the question about the factors deciding about cooperation in the network structure

The factors that were identified as the most important for building network relations can be divided into two basic groups: those related to resources (complementarity of resources, opinion on the quality of these resources), and those associated with the good reputation of the organization itself (experience in establishing cooperation relations, good credit or a system of connections with other organizations). This indicates that the cooperation partner is very often selected based on detailed interviews and analysis of the context. This choice is not accidental, and good reputation evaluation - both of the willingness to cooperate and resources - is an important, if not crucial, factor. The organization's resources can take various forms assessed by the following inquiry. Organizations were asked to indicate, using the same fivepoint Likert scale, elements constituting the resources that have the strongest influence on their willingness to cooperate. The following were mentioned:

- technical infrastructure understood as equipment and facilities available to organizations;

- research infrastructure, i.e. laboratories or particularly efficient R\&D teams; 
- employees or specific personnel working in the organization (knowledge workers).

- knowledge and experience of the organization, manifested in executed projects, held licenses, patents or certificates;

- technological processes taking place in the organization, their efficiency, and effectiveness;

- opinion of the high quality of knowledge management in the organization;

- opinion of the high quality of knowledge and business process management in the organization, management of knowledgeoriented processes;

Process and knowledge management

Knowledge management in organization

Knowledge and experience

Technological processes

Employees

Research infrastructure

Technical infrastructure

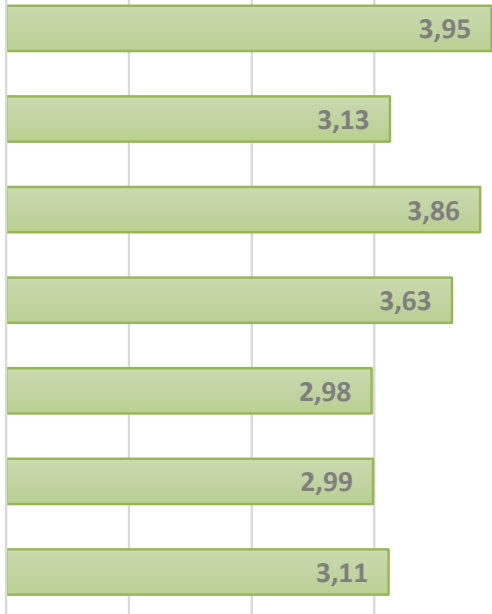

Figure 6. Weighted averages for the response to the question about how resource factors are decisive for cooperation in a network structure

Figure 6 shows the weighted averages of the obtained answers results. The organization's orientation towards the efficiency of knowledge management and processes; that is, the implementation of knowledge-oriented process management requirements is particularly evident. Purely process orientation, the aim of which is to develop the most optimal procedures in the organization, both basic and auxiliary processes, is still an attractive factor, but insufficient in the opinion of modern organizations. Considering the answers obtained as a result of the surveys, it can be assumed that the first hypothesis regarding the significance of the opinion on the quality of business process management and the impact of this assessment on the attractiveness of cooperation partners has been positively verified. 
The second hypothesis says that these processes become a key resource in the implementation of network organization tasks. The aim of the study is to verify whether efficiency in business process management translates into the effectiveness of the entire project implementation, which in turn determines the degree of implementation of the network organization goals. As a result, it can be assumed that this will positively affect the opinion of the partner and this opinion will be reflected in subsequent decisions regarding the creation of a group of colleagues.

Further questions addressed to the respondents focused on whether the good quality of processes that are implemented by one or several cooperation partners positively influenced the three classic dimensions of the project, its scope, time and costs (Figure 7).

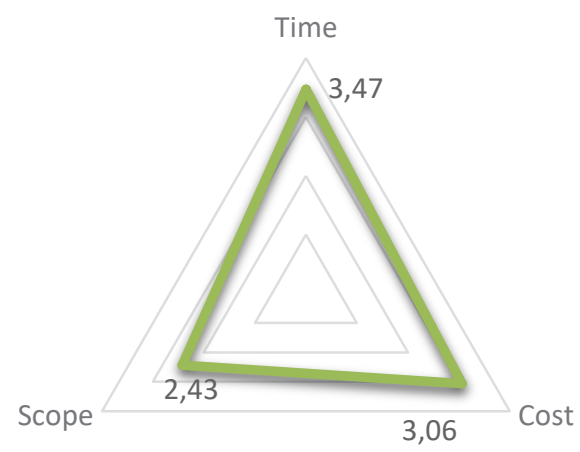

Figure 7. The impact of high-quality processes on the elements of the project triangle

As can be seen in Figure 7, the respondents did not notice the significant impact of process integrity of partners on the project implementation, which does not mean, however, that it does not matter. This question was twofold, it asked for an indication of the impact on a five-point scale, but it also contained an open question. It turns out that the respondents, at the stage of project planning and implementation, took into account the high quality of processes, which in effect was a priori taken into account when planning project activities

When asked about what stage of the project, and to what extent the process efficiency is particularly important, the respondents were in agreement. Already at the level of initiating cooperation, the factor that influences the selection of a partner was the resource in the form of its procedural efficiency. $87.4 \%$ of the surveys pointed to this fact. The ability to rely on an efficiently executed business process is also very important 
in the process of project planning, as indicated by $82 \%$ of respondents. In the opinion of the respondents, the implementation of the project is only the implementation of the agreed action plans. In this way, the second hypothesis was verified positively. It can be concluded that while the high quality of the processes taking place in the organization is not a factor that significantly affects the project already during its implementation, it is a very important condition for the initiation of cooperation, which also confirms the answers given by the respondents under questions about the determinants of network cooperation.

All of the organizations surveyed admitted that they were managed in a procedural way. Each of them has clearly identified processes, and the manner and effectiveness of their implementation is a constant object of interest and monitoring by the organization.

As to the question of whether the project has been modified as a result of the project currently implemented within the organization, then business organizations had the highest proportion of modification of processes, and the smallest extent of modifications occurred in the case of units from the public zone (Figure 8). The latter can be explained by the fact that these units operate under conditions strictly limited by the applicable legal regulations. These modifications were temporary (limited by the time of network collaboration), but the experiences resulting from the implementation of the project in the network structure were, as acknowledged by the respondents, recorded and are to be used in the further functioning of the organization.

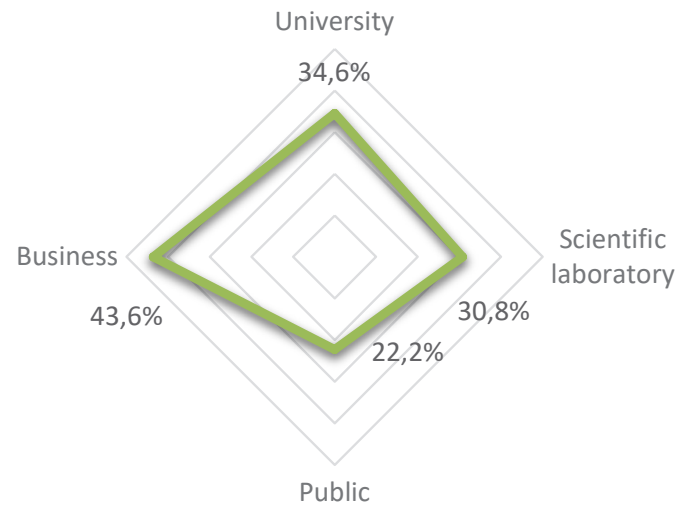

Figure 8. Impact of cooperation on the course of ongoing processes

In each organization, according to the responses of the respondents, there is knowledge management resulting from the project implementation. 
The lessons learned experience, even when this methodology is not required by the project organization, is recorded in the organization databases and information systems. In the case of units representing science (universities and research laboratories), a particular way to use the acquired knowledge and experience is to publish them as reports and post-project articles.

\section{CONCLUSION}

Perfection is very important in the area of processes. The processes that the organization implements in an efficient way are invariably a factor creating a good opinion about that organization. It turns out, however, that they do not exhaust the list of factors. Cooperation with an organization managed in a model business process-oriented way is attractive, although companies are increasingly paying attention to their operation's long-term perspective. That can be observed in the recent emergence of knowledge orientation, where it is knowledge and management of business processes that are the most valued factors when making decisions about cooperation. Organizations respond to changing market demands and high volatility in markets. No market sector is foreign to the necessity to constantly adapt products and services in order to tailor them to the requirements of the modern customer. That, in turn, forces organizations to adapt and modify their processes. Hence, the processes, even the most perfect ones, lose the status of immutability, and the very fact of developing a given process is no longer a guarantor of market success.

This does not imply, however, that business process management is losing its importance. On the contrary, it is an approach that drives the organization to closely reflect on its internal phenomena and activities. As such, business process management prompts organizations to learn not only about the process itself but everything related to its conditions, inputs, and outputs. All of that translates into a huge knowledge base that must be utilized by the organization. Therefore, modern process-oriented enterprises - almost intuitively, on the basis of evolution - lean towards a process and knowledge orientation, with a view to becoming attractive cooperation partners for network organizations

In the introduction to the article, a research question was posed, which states that business process orientation in an organization is one of the most important factors influencing the creation of a network organization. This is evident in the described research. An undoubted limitation of the research presented in the article is its scope. The second is the inhomogeneity of the trial. It was chosen in a targeted manner, among organizations which, according to the author's knowledge, undertook cooperation activities in the form of a network organization. A lack of randomness turns out to be an advantage in 
this case (because it limits the number of surveys in which the obtained answer will exclude the participant from participation in the research, for example, through the lack of experience in cooperation outside the organization's structures). On the other hand, it is a limitation, because these organizations have, in the vast majority, good experience in the field of cooperation.

Results suggest that in the network structures under scrutiny, resources, and abilities to cooperate play a more important role for partnership than the organizational or cultural similarities of the institutions involved. In addition, we found that knowledge management and organizational experience is perceived by participants as more critical for successful cooperation than the quality of personnel.

A flexible and efficient structure, such as a network organization, has to seek "perfect" partners. However, those partners cannot simply recognize the need to adjust their processes; they must also effectively implement them. Management of knowledge-oriented business processes is a means to meet these requirements.

\section{References}

Baretta, A. (2008). The functioning of co-opetition in the health-care sector: An explorative analysis. Scandinavian Journal of Management, 24(3), 209-220. https://doi.org/10.1016/j.scaman.2008.03.005

Bartkowiak, P., \& Koszel, M. (2015). Koopetycja jednostek samorządu terytorialnego. Przeglqqd Organizacji, 9, 59-76.

Birkinshaw, J., \& Sheehan, T. (2002). Managing the knowledge life cycle. MIT Sloan Management Review, 44(1). 75-83.

Bitkowska, A. (2018). Zarządzanie procesowe zorientowane na wiedzę. In G. Gierszewska (Ed.). Co Dalej z Zarzqdzaniem? (pp.19-33). Warszawa: Oficyna Wydawnicza PW.

Brilman, J. (2002). Nowoczesne Koncepcje. Warszawa: Polskie Wydawnictwo Ekonomiczne.

Brynjolfsson, E. \& McAfee, A. (2015). Drugi Wiek Maszyny. Warszawa: MT Biznes.

Brzeziński, M. (2018). Zintegrowane Organizacje Oparte Na Wiedzy. Warszawa: Difin.

Castells, M. (2007). Społeczeństwo Sieci. Warszawa: Polskie Wydawnictwo Naukowe.

Chen, C. J., Huang, J. W., \& Hsiao, Y.C. (2010). Knowledge management and innovativeness: The role of organizational climate and structure. International Journal of Manpower, 31(8), 848-870.

Choong, K.K. (2013). Are PMS meeting the measurement needs of BPM? A literature review. Business Process Management Journal, 19(3), 535574. https://doi.org/10.1108/14637151311319941 
Claver-Cortés, E., Zaragoza-Sáez, P., \& Pertusa-Ortega, E. (2007). Organizational structure features supporting knowledge management processes, Journal of Knowledge Management, 11(4), 45-57 https:// doi:10.1108/13673270710762701

Cygler, J. (2009). Kooperencja Przedsiębiorstw. Czynniki Sektorowe i Korporacyjne. Warszawa: Oficyna Wydawnicza SGH.

Davenport, T., \& Prusak, L. (1998). Working Knowledge - How Organizations Manage What They Know. Boston: Harvard Business School Press.

Deming, E.W. (1986). Out of the Crisis. Cambridge: MIT Press.

Di Ciccio, C., Marrella, A., \& Russo, A. (2015). Knowledge-intensive Processes characteristics, requirements and analysis of contemporary approaches. Journal on Data Semantics, 4(1). 29-57. https://doi:10.1007/s13740014-0038-4

Dollinger, M. (2002). Entrepreneurship: Strategies and Resources. New York: Prentice-Hall.

Gabryelczyk, R., \& Roztocki, N. (2018). Business process management success framework for transition economies. Information Systems Management, 35(3). 234-253. https://doi.org/10.1080/10580530.2018.1477299

Ganzaroli, A., De Noni, I., Orsi, L., \& Belussi, F. (2016). The combined effect of technological relatedness and knowledge utilization on explorative and exploitative invention performance post-M\&A, European Journal of Innovation Management, 19(2). 167-188. https://doi:10.1108/EJIM-082014-0092

Grajewski, P. (2012). Procesowe Zarzqdzanie Organizacja. Warszawa: Polskie Wydawnictwo Ekonomiczne.

Hamel, G. (2007). The Future of Management. Cambridge: Harvard Business School Press.

Hammer, M., \& Champy, J. (1996). Reengineering w Przedsiębiorstwie. Warszawa: Neumann Management Institute.

Hofman, M., \& Skrzypek, E. (2010). Zarzq̨dzanie Procesami w Przedsiębiorstwie Identyfikowanie, Pomiar, Usprawnianie. Warszawa: Wolters Kluwer Polska.

Hugiet-Stańczyk, E., \& Sus, A. (2012). Konsekwencje przynależności do sieci. In J. Niemczyk, E. Stańczyk-Hugiet, \& B. Jasiński (Eds.). Sieci Międzyorganizacyjne. Współczesne Wyzwania dla Teorii i Praktyki Zarzq̨dzania (pp.86-96). Warszawa: C.H. Beck.

Kakabadse, N. K., Kakabadse, A., \& Kouzmin, A. (2003). Reviewing the knowledge management: Towards a taxonomy. Journal of Knowledge Management, 7(4).75-91.https://doi.org/10.1108/13673270310492967

Kirkpatrick, D. (2011). Beyond Empowerment: The Age of the Self-Managed Organization. New York: Morning Start, Self-Management Institute.

Kisielnicki, J., \& Sobolewska, O. (2019). Knowledge Management and Innovation in Network Organizations. Emerging Research and Opportunities. Hershey: IGI Global.

Łobejko, S. (Ed.). (2012). Przedsiębiorstwa Sieciowe i Inne Formy Współpracy Sieciowej. Warszawa: Oficyna Wydawnicza SGH. 
Matthews, J., \& Schulman, A. (2005). Competitive advantage in public sector organizations: Explaining the public good/sustainable competitive advantage paradox. Journal of Business Research, 58, 232-240. https:// doi:10.1016/S0148-2963(02)00498-8

McCormack, K., Johnson, W. C. (2001). Business Process Orientation: Gaining the E-Business Competitive Advantage. Boca Raton: St Lucie Press.

Merrifield, D. B. (2007). Strategic collaborations - essence of survival. Research Technology Management, 50(2). 10-14. https://doi.org/10.10 80/08956308.2007.11657424

Mikuła, B. (2006). Organizacje Oparte na Wiedzy. Kraków: Wydawnictwo Akademii Ekonomicznej.

Mills, A. M., \& Smith, T. A. (2011). Knowledge management and organizational performance: A decomposed view. Journal of Knowledge Management, 15(1). 156-71. https://doi.org/10.1108/13673271111108756

Nadarajah, D., \& Kadir, S. L. (2016). Measuring business process management using business process orientation and process improvement initiatives. Business Process Management Journal, 22(6),1069-1078. https:// doi:10.1108/bpmj-01-2014-0001

Nguyen, H. N., \& Mohamed, S. (2011). Leadership behaviors, organizational culture and knowledge management practices: An empirical investigation. Journal of Management Development, 30(2), 206-221. https://doi:10.1108/02621711111105786

Niemczyk, J., Stańczyk-Hugiet, E., \& Jasiński, B. (2012). Sieci Międzyorganizacyjne. Współczesne Wyzwania dla Teorii i Praktyki Zarzqdzania. Warszawa: C.H. Beck.

Nooteboom, B., Van Haverbeke, W., Duysters, G., Gilsing, V., \& Van de Oord, A. (2007). Optimal cognitive distance and absorptive capacity. Research Policy, 36(7), 1016-1034. https://doi.org/10.1016/j.respol.2007.04.003

O'Dell, C., \& Grayson, C. J. (1998). If only we knew what we know: Identification and transfer of internal best practices. California Management Review, 40(3). 154-174. https://doi.org/10.2307/41165948

Porter, M.E. (1985). Competitive Advantage: Creating \& Sustaining Superior Performance. New York: The Free Press.

Pronshikh, V., \& Sobolewska, O. (2018). Coopetition model of knowledge sharing in science: An Eastern-European case study. Acta Physica Polonica B. Proceedings Supplement, 11. 803-823. https://doi:10.5506/ APhysPolBSupp.11.803

Ravesteyn, P., \& Batenburg, R. (2010). Surveying the critical success factors of BPM-systems implementation, Business Process Management Journal, 16(3), 492-507. https://doi:10.1108/14637151011049467

Robertson, B. (2015). Holacracy: The New Management System for a Rapidly Changing World. USA: Henry Holt and Co.

Rummler, G., \& Brache, A. (2000). Podnoszenie Efektywności Organizacji. Jak Zarzadzać „Białymi Plamami” w Strukturze Organizacyjnej? Warszawa: Polskie Wydawnictwo Ekonomiczne. 
Snow, C. C., Miles, R. E., \& Coleman, H. J. (1992). Managing 21 $1^{\text {st }}$-century network organizations. Organizational Dynamics, 20(3), 5-20.

Sobolewska, O. (2016). Kooperencja w biznesie i na uczelniach wyższych - czynniki wpływające na decyzje o relacjach współpracy. In P. Bartkowiak \& A. Jaki (Eds.), Dylematy Rozwoju Nauk o Zarzqdzaniu. Perspektywa Metodologiczna (pp. 104-119). Toruń: Dom Organizatora.

Szczepańska, K., \& Bugdol, M. (2016) Podstawy Zarzqdzania Procesami. Warszawa: Difin.

Szelągowski, M. (2018). Zarzqqdzanie Procesowe w Gospodarce Wiedzy. Tworzenie Wartości z Kapitału Intelektualnego. Warszawa: Wydawnictwo Linia.

Teece, D. J., Pisano, A., \& Shuen, A. (1997). Dynamic capabilities and strategic management. Strategic Management Journal, 18(7), 509-533.

Tubielewicz, A. (2013). Koncepcja tworzenia organizacji sieciowej. Efektywność, Produktywność i Organizacja Przedsiębiorstw. Zarzqdzanie Przedsiębiorstwem, 36, 387-397.

Walsh, J. P., \& Ungson, G. R. (1991). Organizational memory. Academy of Management Review, 16(1), 57-91. https://doi.org/10.5465/ amr.1991.4278992

Zollo, M., \& Winter, S. G. (2002). Deliberate learning and the evolution of dynamic capabilities. Organization Science, 13(3), 339-351. https://doi. org/10.1287/orsc.13.3.339.2780

Zott, C., \& Amit, R. (2010). Designing your future business model: An activity system perspective. Long Range Planning, 43, 216-226. https:// doi:10.1016/j.Irp.2009.07.004

\begin{abstract}
Abstrakt
Współcześnie coraz częściej mamy do czynienia z powstawaniem organizacji o charakterze sieciowym. Sq to organizacje zakładane w celu realizacji konkretnych zadań i sq tworzone przez niepowiqzane organizacje. Wybór kooperanta nie może być i nie jest przypadkowy. Jest to proces, w którym wykorzystywana jest wiedza o ewentualnym partnerze i jego zasobach, a także możliwościach. Autorka stawia tezę, iż orientacja organizacji na procesy, a także na zarzqdzanie wiedza jest silnq determinanta dla podejmowania współpracy sieciowej. W celu weryfikacji tak sformułowanego pytania, została przeprowadzona ankieta. Pytania o czynniki wpływajqce na decyzję o podjęciu działania współpracy w ramach struktury sieciowej, zostały skierowane do grupy nielosowej. Organizacje, które uczestniczyły w badaniu, majq doświadczenie w prowadzeniu projektów w ramach struktury sieciowej. Badanie ma charakter przyczynkowy, może być jednak punktem wyjścia dla dalszych rozważań oraz do próby budowy modelu o charakterze ogólnym.
\end{abstract}

Słowa kluczowe: organizacja sieciowa, zarzqdzanie procesowe, zarzqdzanie procesowe zorientowane na wiedzę, determinanty współpracy, proces zarzqdzania wiedzq, organizacja elastyczna 


\section{Biographical note}

Olga Sobolewska, IT engineer and Ph.D. in economics in the field of management science. She is a graduate of the Faculty of Management at the UW and works at the Faculty of Management at the WUT. She is a member of TNOiK (Scientific Society of Organization and Management) and NTIE (Scientific Society of Economic Information Technology). Her scientific specialty is the application of information systems in organizations. She is interested in project management and the organization's evolution towards a network of connections, the alteration of traditional structures into network, and hybrid. 